American Journal of Environmental Sciences 3 (3): 135-142, 2007

ISSN 1553-345X

(C) 2007 Science Publications

\title{
Foundry Wastes Reuse and Recycling in Concrete Production
}

\author{
Silvia Fiore, Maria Chiara Zanetti \\ DITAG - Politecnico di Torino - C.so Duca degli Abruzzi 24, 10129 - Torino, Italy
}

\begin{abstract}
The industrial process of a cast iron foundry plant located in the North of Italy was analyzed in order to determine the amount and kind of produced wastes. The main fractions are core and moulding sands, muds and powders from dust abatement plants, furnace and ladle slags, and exhaust lime, making about 750-800 t/d of residues for a production of about $800 \mathrm{t} / \mathrm{d}$ of globular and grey cast iron. All wastes were sampled and characterized by means of particle-size distribution and chemical analyses to evaluate the best reuse and recycling solutions. On the grounds of the gathered results, the residues may be divided in three categories according to the particle-size dimensions: below $0.1 \mathrm{~mm}$, between 0.1 and $0.6 \mathrm{~mm}$ and above $0.6 \mathrm{~mm}$. The fraction above $0.6 \mathrm{~mm}$, mainly made of metallic iron, may be reused in the furnaces. The fraction between $0.1 \mathrm{~mm}$ and $0.6 \mathrm{~mm}$ may be reused in cores production, after a regeneration treatment. The fraction between 0.1 and $0.025 \mathrm{~mm}$ may be recycled as raw material for the concrete industry, and the below $0.025 \mathrm{~mm}$ fraction may be reused in green moulding operations. An economic evaluation of the proposed reuse and recycling solutions was performed.
\end{abstract}

Keywords: Foundry waste, reuse, recycling, bentonite bonded moulding sand, green sand moulding, concrete.

\section{INTRODUCTION}

Exhaust sands represent a vital issue in the management of foundry wastes: a ferrous foundry of secondary fusion produces an amount of residues varying from $25 \%$ to $100 \%$ b.w. respect to the final product, and the $30-60 \%$ of these wastes is made of core and moulding sands ${ }^{[1]}$.

Green sand moulding, accounting for about the $85 \%$ of cast iron produced in the world ${ }^{[2]}$, employs a mixture of silica sand ( $80-95 \%$ b.w.), clay (3-10\% b.w.), coal dust $\left(2-10 \%\right.$ b.w.) and water $\left(3-4 \%\right.$ b.w.) ${ }^{[3]}$. The word "green" denotes the absence of any drying or baking phase ${ }^{[4]}$. Water activates the binding action of the clay on silica sand, and the coal dust burns off at the contact with the molten metal, preventing its oxidation and increasing the refractory properties of the mould.

Cores are made of silica sand and organic binders, and should be harder and stronger than moulds, because they must bear the pressure of the molten metal that fills the mould ${ }^{[5]}$.

The reclamation of exhaust moulding sands for the recycling in core production is essentially based on the following aspects ${ }^{[2,3,6-8]}$ : a proper particle-size range (usually between 0.1 and $0.4-0.6 \mathrm{~mm}$ ) and the elimination of bentonite, coal dust and metallic plus non metallic impurities. The dimensional range and the coal dust and impurities elimination may be easily achieved by means of a sieving operation (metal particles and mould and core fragments cumulate preferentially in large fractions, while coal dust is particularly present in fine fractions) and a magnetic separation phase. Bentonite is located as free particles in fine fractions, but also forms a hard shell (defined "oolitic") that surrounds the silica grains, which may be broken by means of mechanical treatments. The reclamation of exhaust foundry sands coming out from cores shakeout usually foresees a sieving phase and a magnetic separation and a final thermal treatment to eliminate organic binders residues.

The aim of this work, on the grounds of a careful analysis of the waste flows of a Teksid foundry plant located in Northern Italy, producing cast iron by means of a secondary fusion process, is to evaluate any potential reuse/recycling possibility for about $450 \mathrm{t} / \mathrm{y}$ of wastes, actually landfilled.

\section{A Teksid cast iron foundry plant}

The Teksid cast iron foundry plant considered in this research actually produces about $700-800 \mathrm{t} / \mathrm{d}$ of casts of globular and grey cast iron for the automotive industry and about $750-800 \mathrm{t} / \mathrm{d}$ of wastes. The secondary fusion process is made of the following phases: furnace charge preparation, mould and core manufacture, pattern making, melting and casting, shakeout, cleaning and finishing operations. Green sand moulding and hot/cold box processes are performed respectively for mould and core manufacture.

The cast iron production in the examined plant is realized in two furnaces with a total capacity equal to

Corresponding Author: Silvia Fiore, DITAG (Dipartimento del Territorio, dell'Ambiente e delle Geotecnologie) Politecnico di Torino, c.so Duca degli Abruzzi 24, 10129 - Torino, Italy 
$80 \mathrm{t} / \mathrm{h}$. The furnace charge varies according to the kind of production (globular iron or grey cast iron) and it is made of iron and steel residues (i.e. coming from the car demolition), coke, calcium carbide and silica carbide. Iron desulphurisation for the globular iron production is performed in a ladle by means of lime addition.

The melt is performed in three production lines where moulds and cores are assembled to form the pattern. After the melt and a cooling phase, the cast shakeout, cleaning and finishing operations are realized in order to eliminate sand, fine particles and the metal particles by means of a sieving operation, two phases of steel shotting, a painting and a thermal treatment.

Table 1: Wastes produced in Teksid foundry plant

\begin{tabular}{|c|c|c|c|}
\hline Sample (ID) & Origin & $\begin{array}{c}\text { Quantity } \\
(\mathrm{t} / \mathrm{d})\end{array}$ & Destination \\
\hline $\begin{array}{l}\text { Moulding } \\
\text { sand (MS1) }\end{array}$ & Shakeout operation & 360 & $\begin{array}{l}\text { External } \\
\text { regeneration, } \\
\text { landfill, } \\
\text { concrete } \\
\text { industry }\end{array}$ \\
\hline $\begin{array}{l}\text { Moulding } \\
\text { sand (MS2) }\end{array}$ & $\begin{array}{l}\text { Shakeout under } \\
\text { level }\end{array}$ & 45 & $\begin{array}{l}\text { Landfill or } \\
\text { concrete } \\
\text { industry }\end{array}$ \\
\hline $\begin{array}{l}\text { Dust and } \\
\text { moulding } \\
\text { sand (MS3) }\end{array}$ & $\begin{array}{l}\text { Metal particles and } \\
\text { first steel shotting } \\
\text { operation }\end{array}$ & 45 & $\begin{array}{l}\text { Landfill or } \\
\text { concrete } \\
\text { industry }\end{array}$ \\
\hline $\begin{array}{l}\text { Filtered and } \\
\text { pressed mud } \\
\text { (TH1) } \\
\text { Filtered and } \\
\text { pressed mud } \\
(\mathrm{TH} 2)\end{array}$ & $\begin{array}{l}\text { Wet dust abatement } \\
\text { plant of furnace } 1 \\
\text { (Theisen) } \\
\text { Wet dust abatement } \\
\text { plant of furnace } 2 \\
\text { (Theisen) }\end{array}$ & 30 & Landfill \\
\hline $\begin{array}{l}\text { Filtered and } \\
\text { pressed mud } \\
(\text { FPM) }\end{array}$ & $\begin{array}{l}\text { Wet dust abatement } \\
\text { plant of molding } \\
\text { lines } 3,4 \text { e B }\end{array}$ & 120 & Landfill \\
\hline $\begin{array}{l}\text { Dusts } \\
\text { (MD1) }\end{array}$ & $\begin{array}{l}\text { Dust abatement } \\
\text { plant of moulding } \\
\text { lines } 4 \text { e B } \\
\text { (Stranich) } \\
\text { Dust abatement } \\
\text { plant of moulding } \\
\text { line B (Siat) }\end{array}$ & 3 & $\begin{array}{l}\text { Concrete } \\
\text { industry }\end{array}$ \\
\hline $\begin{array}{l}\text { Dusts (SH1) } \\
\text { Dusts (SH2) }\end{array}$ & $\begin{array}{l}\text { Finishing, shotting } \\
\text { (Disa) } \\
\text { Finishing, shotting } \\
\text { (Berger-Fisher) }\end{array}$ & $2-3$ & Landfill \\
\hline Dusts (FD) & $\begin{array}{l}\text { Dust abatement } \\
\text { plant of furnaces }\end{array}$ & 5 & Landfill \\
\hline Dusts (CR) & $\begin{array}{l}\text { Core sand } \\
\text { regeneration }\end{array}$ & 6 & Landfill \\
\hline Dusts (FP) & Foundry pavement & 2 & Landfill \\
\hline Slags & Furnaces, ladles & 100 & $\begin{array}{l}\text { Concrete } \\
\text { industry }\end{array}$ \\
\hline Exhaust lime & $\begin{array}{l}\text { Globular iron } \\
\text { desulphurization }\end{array}$ & 6 & Landfill \\
\hline Sands & Broken cores & 50 & $\begin{array}{l}\text { Internal } \\
\text { regeneration } \\
\text { and landfill }\end{array}$ \\
\hline $\begin{array}{l}\text { Not inert } \\
\text { fine particles } \\
(\mathrm{NIF})\end{array}$ & $\begin{array}{l}\text { Moulding sand } \\
\text { regeneration }\end{array}$ & $54 *$ & - \\
\hline $\begin{array}{l}\text { Inert fine } \\
\text { particles (IF) }\end{array}$ & $\begin{array}{l}\text { Moulding sand } \\
\text { regeneration }\end{array}$ & $18 *$ & - \\
\hline
\end{tabular}

The involved foundry plant employs two methods for core production: the hot-box process, in which silica sand is mixed with $1 \%$ b.w. phenolic resin and $0.8 \%$ b.w. of ammonium nitrate and urea as catalysts, and then heated at $230-260^{\circ} \mathrm{C}$ until solidification; in the cold-box process silica sand is mixed with $1.3 \%$ b.w. phenolic resin, $0.9 \%$ b.w. isocyanic resin and $0.1 \%$ b.w. trimethylamine gas as catalyst, and no heating is required.

The produced wastes are made of moulding sands (360 $\mathrm{t} / \mathrm{d})$, muds from dust abatement plants on furnaces and moulding lines $(150 \mathrm{t} / \mathrm{d})$, furnace and ladle slags (100 $\mathrm{t} / \mathrm{d})$, powdered sands from shakeout and shotting (90 $\mathrm{t} / \mathrm{d}$ ), broken cores $(50 \mathrm{t} / \mathrm{d})$, dust from dust abatement plants on furnaces, moulding lines, finishing operations and pavements $(12 \mathrm{t} / \mathrm{d})$, powders from the core thermal regeneration plant $(6 \mathrm{t} / \mathrm{d})$, exhaust lime from the desulphurisation operation $(6 \mathrm{t} / \mathrm{d})$. The abovementioned wastes are schematised in Table 1, together with their description, quantities and destinations. The residues marked in bold in Table 1 were sampled and characterized by the authors by means of particle-size distribution and chemical analyses, and some treatments were tested to evaluate the best reuse/recycling solutions in foundry operations and in concrete production, keeping into account the economic aspects.

Actually the main fraction (about the $60 \%$ b.w.) of the wastes coming out from the foundry plant ias landfilled; a minor part (about the $10-15 \%$ b.w.) is recycled in concrete production. The other wastes, made of moulding sands and broken cores, are partially reused for core making after some regeneration treatments performed in internal and external plants. Moulding sands are actually recovered for cores production by means of a dry mechanical plus thermal treatment, described in section 3. At the moment of this research the plant was in the starting phase and the moulding sands reclamation was performed in an external plant by means of a wet mechanical treatment, nevertheless the main part of the exhaust moulding sands were landfilled. The regeneration treatment of a fraction of the broken cores is performed in another plant (named "thermal plant" and located in the foundry area), which realizes the following phases: crushing of the wastes in a vibromill, magnetic separation, screening of the amagnetic fraction to eliminate the above $5 \mathrm{~mm}$ particles, dry scrubbing, thermal treatment at $800^{\circ} \mathrm{C}$, screening to eliminate the above $0.8 \mathrm{~mm}$ fraction, dry scrubbing, final screening to eliminate the below 0.1 $\mathrm{mm}$ fine particles.

\section{The exhaust moulding sands reclamation process:}

A dry mechanical plus thermal process is applied in a treatment plant situated in the considered foundry plant. The regeneration process is schematised in Figure 1: after a sieving and a magnetic separation (that allows 


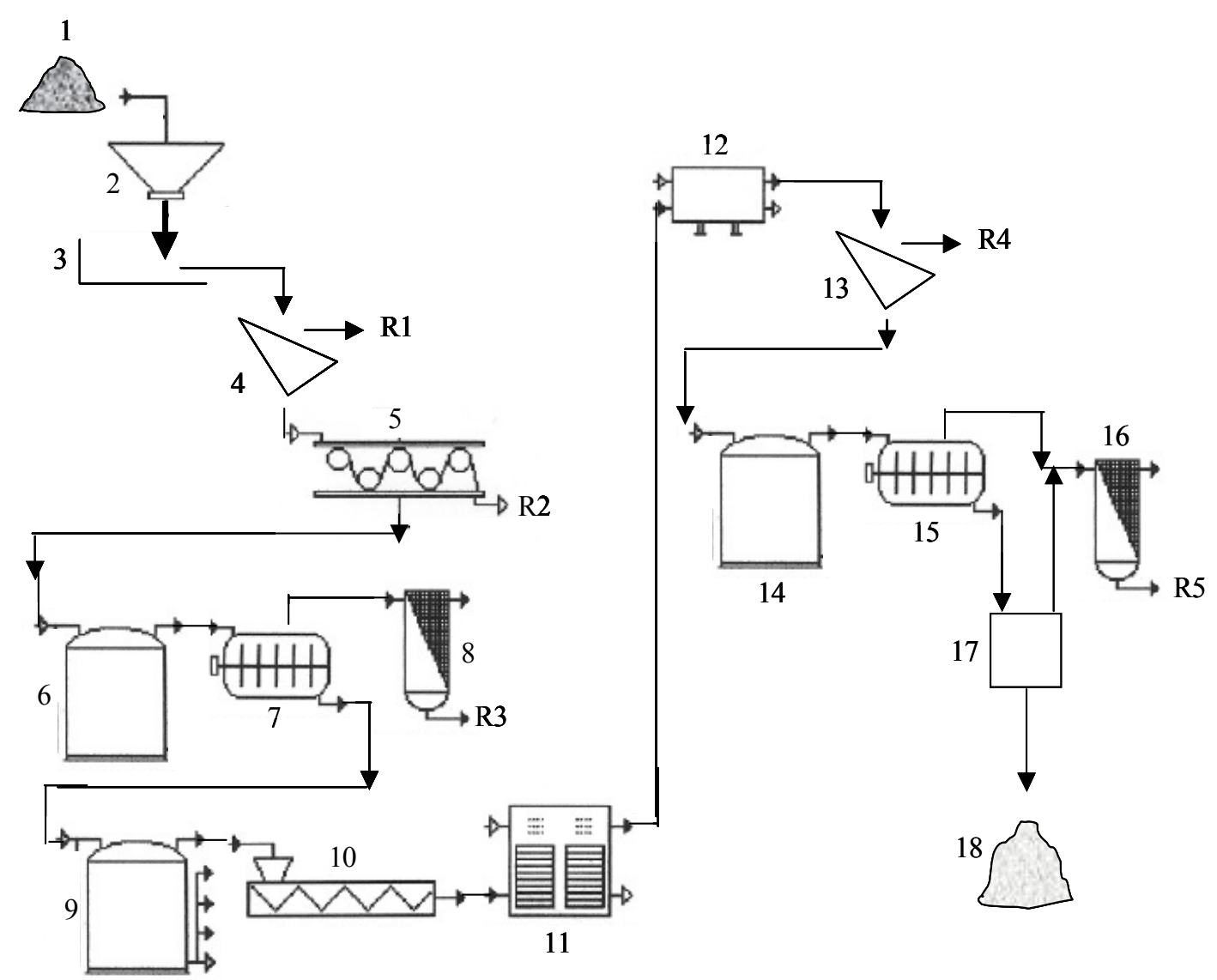

Legend of Fig. 1: 1. feed, 2. shaking feeder, 3. shaking extractor, 4. screen, R1. iron residues (d $>0.6 \mathrm{~mm})$, 5. magnetic belt separator, R2. magnetic fraction, 6. storage, 7. scrubber (high intensity), 8 and 16. dedusting (cyclone and bag filter), R3. not inert fine particles, 9. storage, 10.screw conveyor, 11. Hot Rec furnaces, 12. cooling, 13. sieve, R4. residues (d $>0.4 \mathrm{~mm})$, 14. storage, 15. scrubber (low density), R5. inert fine particles, 17. dedusting, 18. final product

Fig. 1: Scheme of the dry mechanical plus thermal reclamation treatment of exhausted foundry sand adopted in Teksid foundry plant.

the separation of the $\mathrm{d}>0.6 \mathrm{~mm}$ fraction made of $90 \%$ b.w. metallic iron), there is a low intensity pneumatic mechanical scrubbing treatment, followed by a thermal treatment at the temperature of $800 \div 900{ }^{\circ} \mathrm{C}$ and finally by a high intensity pneumatic mechanical scrubbing treatment. The plant is designed to perform the reclamation of $600 \mathrm{t} / \mathrm{d}$ of green moulding sands for core manufacture, with a theoretical silica sand recovery equal to the $80 \%$ b.w..

The produced residues are mainly of two kinds: not inert fine particles ( $15 \%$ b.w. of the feed) and inert fine particles ( $5 \%$ b.w. of the feed). The word "inert" refers to a minimum content of active clay that may characterize the thermal resistance of the bentonite employed in green sand moulding.

At the moment of this study the plant was in the starting phase, and a laboratory sample of not inert fine particles was obtained. No sample of the inert fine particles were available: the authors assume that this residue may be
If the reclamation plant is fed on $360 \mathrm{t} / \mathrm{d}$ of moulding sands coming from shakeout operations (sample MS1), the residues amount may be evaluated equal to $54 \mathrm{t} / \mathrm{d}$ of not inert fine particles and $18 \mathrm{t} / \mathrm{d}$ of inert fine particles (see Table 1).

\section{MATERIALS AND METHODS}

All the analyses were performed on dried samples, performing reference procedures [9] and employing A.C.S. grade reagents.

All the considered waste materials were collected by the authors with full care in obtaining representative samples of about $5-10 \mathrm{~kg}$. The particle-size analysis was realized on samples reduced to a mass of about 400 $\mathrm{g}$ by means of a Jones splitter, using a Ro-Tap Tyler mechanical siever equipped with six Tyler mesh sieves $\left(2^{1 / 4}\right.$ ratio) for 10 minutes. All the weighing operations were performed by means of a Mettler balance $(0.01 \mathrm{~g}$ 
sensitivity). The inflow samples were at first wet sieved at a $0.025 \mathrm{~mm}$ and $0.038 \mathrm{~mm}$ dimension before the particle size analysis. The particle-size analysis below the $0.025 \mathrm{~mm}$ dimension was performed by means of an Andreasen apparatus.
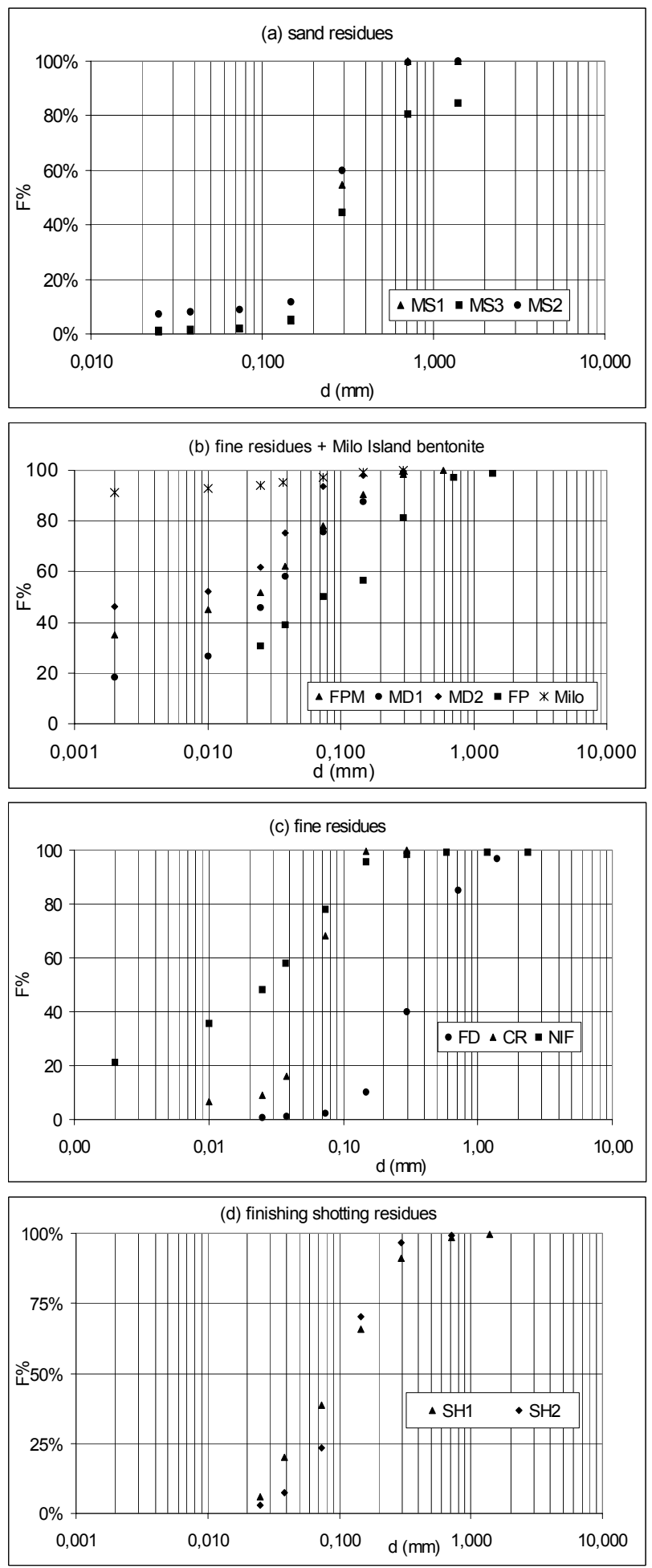

Fig.2: Particle-size analysis of some foundry plant residues
The active clay content was gathered by means of titration with a methylene blue solution of the liquid phase made by the samples in acidified distilled water. The obtained results were explained by means of a calibration based on the titration of the Milo Island bentonite, employed as a raw material in the foundry plant.

The physical properties of the samples that are able to define the clay formability were studied through the determination of the Atterberg limits (liquidity and plasticity limits $W_{L}$ and $W_{P}$, and plasticity index IP) by means of a Casagrande Apparatus.

The Loss on Ignition (L.O.I.) value was evaluated by roasting $2 \mathrm{~g}$ of dried sample at the temperature of $900^{\circ} \mathrm{C}$ for 3 hours. The weight difference (\% b.w.) between the starting sample and the roasted one gives the searched value.

Some metals ( $\mathrm{Na}, \mathrm{K}, \mathrm{Ca}, \mathrm{Mg}, \mathrm{Fe}, \mathrm{Mn}, \mathrm{Cr}, \mathrm{Cu}, \mathrm{Pb}, \mathrm{Ni}$, $\mathrm{Zn}, \mathrm{Al})$ contents were obtained through an acid digestion of $0.5 \mathrm{~g}$ sand with $6 \mathrm{ml}$ of $32 \%$ hydrochloric acid and $2 \mathrm{ml}$ of $65 \%$ nitric acid in a Milestone 1200 Mega microwave oven. The digested samples were filtrated on Whatman grade 44 filters and on the obtained solutions the metals contents determination was performed by means of a Perkin-Elmer 1100B FAAS. For the silica determination the filtered solid residue underwent to a calcination phase $\left(900{ }^{\circ} \mathrm{C}\right.$ for 30 minutes) and a new acid digestion in the microwave oven with $6 \mathrm{ml}$ of $40 \%$ fluoridric acid. The obtained solution is filtrated and the solid residue was calcinated at $900{ }^{\circ} \mathrm{C}$ for 30 minutes.

The Aluminium content was gathered through an acid digestion of $0.25 \mathrm{~g}$ samples with $2 \mathrm{ml}$ of $96 \%$ sulphuric acid and $2.5 \mathrm{ml}$ of $85 \%$ phosphoric acid in a Milestone 1200 Mega microwave oven. $5 \mathrm{ml}$ of $40 \%$ fluoridric acid were added to the digested samples and a new digestion phase was performed. The digested samples were filtrated on Whatman grade 44 filters and on the obtained solutions the Aluminium content determination was performed by means of a PerkinElmer 1100B FAAS.

Sulphates, chlorides and phosphates contents were determined by means of a UNICAM Helios $\alpha$ UVVisible spectrometer, according to reference procedures [10]. The analyses were performed on the liquid phase, filtered on a $0.45 \mu \mathrm{m}$ membrane, obtained from a 24 hours contact between $5 \mathrm{~g}$ of sample and $500 \mathrm{ml}$ of distilled water.

\section{DISCUSSION AND RESULTS}

The results of the particle-size analysis of the considered foundry plant residues are shown in Figure 2.

In order to evaluate the reuse of the samples rich of fine particles, the Atterberg limits (liquidity limit $\mathrm{W}_{\mathrm{L}}$, plasticity limit $\mathrm{W}_{\mathrm{P}}$, and plasticity index $\mathrm{I}_{\mathrm{P}}$ ) and the active clay content were measured on the below 0.025 
$\mathrm{mm}$ fraction of the above mentioned residues. The Atterberg limits values are reported in Table 2.

Table 2: Active clay content and Atterberg limits of Teksid foundry plant fine residues

\begin{tabular}{cccccc}
\hline \multicolumn{7}{c}{$\begin{array}{c}\text { (measured on } \mathrm{d}<0.025 \mathrm{~mm}) \\
\% \\
\text { sample }\end{array}$} & $\begin{array}{c}\% \mathrm{~d}<0.025 \\
\mathrm{~mm}\end{array}$ & $\begin{array}{c}\% \\
\text { active } \\
\text { clay }\end{array}$ & $\% \mathrm{~W}_{\mathrm{L}}$ & $\% \mathrm{~W}_{\mathrm{P}}$ & $\% \mathrm{IP}$ \\
\hline $\mathrm{MS} 2$ & 7.3 & 42.1 & 113.5 & 28.4 & 85.1 \\
$\mathrm{FPM}$ & 51.8 & 6.1 & 102.6 & 45.1 & 57.5 \\
$\mathrm{MD} 1$ & 46.0 & 4.0 & 45.1 & 38.8 & 6.3 \\
MD2 & 61.9 & 36.3 & 97.1 & 25.3 & 71.8 \\
FP & 30.7 & 29.4 & 86.5 & 28.3 & 58.2 \\
NIF & 48.4 & 37.9 & 89.4 & 30.2 & 59.2 \\
Milo & & & & & \\
$\begin{array}{c}\text { island } \\
\text { bentonite }\end{array}$ & 94.2 & 90.0 & $/$ & $/$ & $/$ \\
\hline
\end{tabular}

The results of the chemical analyses performed on the considered waste materials and on samples of Milo island bentonite and mineral coal employed as raw materials in the Teksid foundry plant are schematized in Tables 3. Samples CR, FPM and MD1 underwent other chemical analyses: chloride, sulphate and phosphorous

content were determined in order to evaluate their potential reuse in the concrete industry. The results are shown in Table 4.

Considering sand residues (see Figure 2a), sample MS1 has a particle-size distribution varying from 0.1 to 0.6 $\mathrm{mm}$, in agreement with the requirements of the raw silica sand employed in the foundry plant for core dressing; sample MS2, compared with sample MS1, has a higher fine fraction $(12 \%$ b.w. below $0.1 \mathrm{~mm})$, probably made of coal dust and clay; sample MS3 has instead a relevant coarse fraction $(20 \%$ b.w. above 0.6 $\mathrm{mm}$ ), made of steel shotting particles. The particle-size

Table 3: Chemical characterization of the considered wastes, and of Milo island bentonite and mineral coal employed in Teksid foundry plant

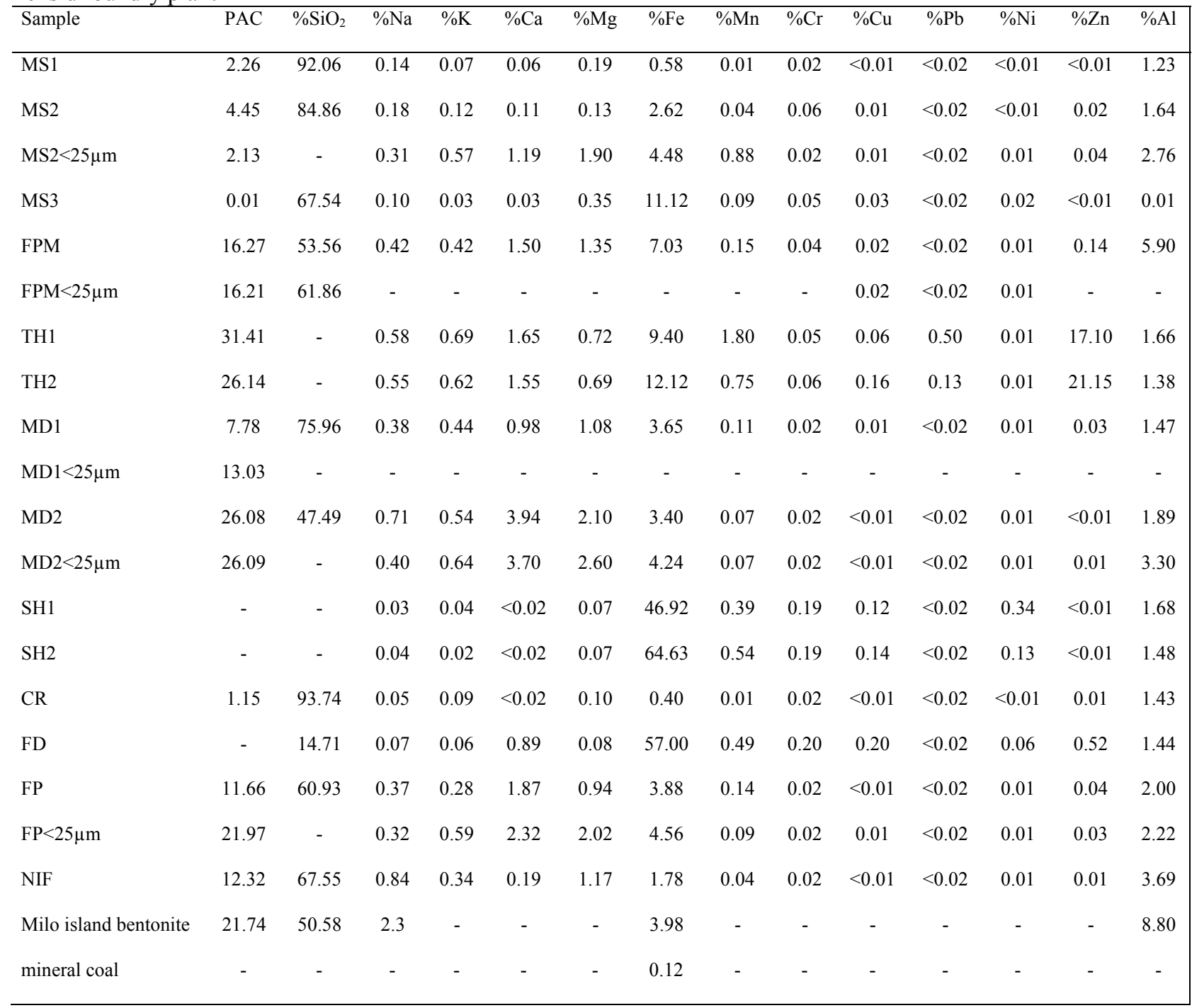


distributions of fine residues (see Figure $2 b$ and $2 c$ ) show that dusts and muds have dimensions below 0.1 mm (samples FP and FD excepted). Samples FPM, MD1, FP and NIF, because of their origin, are mostly made of coal dust and clay. The Milo Island clay, a sodium substituted bentonite employed in foundry for moulding operations, has dimensions mostly below $0.01 \mathrm{~mm}$ (see Figure 2b). Sample FD is essentially made of the materials making the furnace charge (i.e. iron and steel, silica carbide), and sample CR is constituted of fine silica particles deriving from the thermal regeneration of core sands, with a fraction below $0.1 \mathrm{~mm}$ equal to $85 \%$ b.w.. Residues coming from finishing shotting (see Figure 2d) are characterized by a large fraction above $0.1 \mathrm{~mm}(>50 \%$ b.w.), rich of steel shotting particles and cast iron fragments. Not inert fine particles sample (NIF) coming from moulding sand reclamation treatment exhibits a fraction below $0.1 \mathrm{~mm}$ about equal to $90 \%$ b.w..

Table 4: Comparison of the chemical characteristics of some Teksid plant fine residues with the concrete industry requirements.

\begin{tabular}{|ccccc|}
\hline Samples $\rightarrow$ & FPM & MD1 & CR & $\begin{array}{c}\text { Concrete industry } \\
\text { requirements (\%) }\end{array}$ \\
\hline $\mathrm{CaO}$ & 2.098 & 1.371 & $<0.028$ & $60-69$ \\
$\mathrm{SiO}_{2}$ & 53.560 & 75.96 & 93.74 & $18-24$ \\
$\mathrm{Al}_{2} \mathrm{O}_{3}$ & 11.153 & 2.779 & 2.703 & $4-8$ \\
$\mathrm{Fe}_{2} \mathrm{O}_{3}$ & 10.057 & 5.222 & 0.572 & $1-8$ \\
$\mathrm{MgO}$ & 2.239 & 1.791 & 0.166 & $<5$ \\
$\mathrm{Na}_{2} \mathrm{O}+\mathrm{K}_{2} \mathrm{O}$ & 1.072 & 1.042 & 0.175 & $<2$ \\
$\mathrm{SO}_{4}{ }^{2}$ & 0.059 & 0.092 & $<0.01$ & $<0.2$ \\
$\mathrm{Cl}^{-}$ & 0.017 & 0.058 & 0.011 & $<0.1$ \\
$\mathrm{P}_{2} \mathrm{O}_{5}$ & 0.002 & 0.002 & 0.002 & $<2.5$ \\
\hline
\end{tabular}

Moulding sands (MS1) will be sent to the dry mechanical plus thermal plant described in section 2 . Considering particle-size analysis results, sand residues (MS2, MS3) may be reused in cores production, after coal dust, clay and organic fraction removal; the residues containing a coarse fraction made of ferrous materials (FD, SH1, SH2) may be reused for the furnace charge; the residues rich of coal and clay (MS2, FPM, MD1, MD2, FP, NIF) may be reused in mould dressing with the addition of new coal dust and bentonite. The Atterberg limits (liquidity limit $\mathrm{W}_{\mathrm{L}}$, plasticity limit $\mathrm{W}_{\mathrm{P}}$, and plasticity index $\mathrm{I}_{\mathrm{P}}$ ) and active clay content values (see Table 2), show that the below $0.025 \mathrm{~mm}$ fractions of samples MS2, MD2, FP and NIF are characterized by good values of the active clay content $(29 \div 42 \%)$, and by good consistency parameters values, typical of an inorganic clay with high plasticity characteristics, therefore the reuse in mould production of the below $0.025 \mathrm{~mm}$ fraction of these samples is possible.

Considering the results of the chemical analyses (see Table 3), sand residues MS1 and MS2 have a high silica content (respectively $92 \%$ and $85 \%$ b.w.) and sample MS3 is characterized by a noticeable iron fraction (about 11\% b.w.). SH1, SH2 (finishing shotting dusts) and FD (furnace dusts) wastes are particularly rich of metallic iron (respectively $50 \%, 64 \%$ and $57 \%$ b.w.) that may be recovered and recycled in the charge of the furnace. CF residue (dust from the thermal reclamation of spent core sands) has a very high silica content (about 94\% b.w.). Mud samples coming from the wet dust-abatement plant on the furnaces (TH1 and $\mathrm{TH} 2$ ) have a noticeable heavy metals content, particularly zinc and lead, that confirms the adoption of the landfilling solution.

A possible reuse solution for the residues rich of particles below $0.1 \mathrm{~mm}$ and silica (FPM, MD1, CR) may be the recycling in concrete production, after the addition of new raw materials. Sample FPM, containing the $30 \%$ b.w. of water, must be pelletized and dried before the recycling. Some tests, performed on a $30 \mathrm{~kg}$ sample, allowed the authors to evaluate the pelletization and drying cost at about $7 € / \mathrm{t}$ of mud.

Concrete industry, for the most part producing Portland concrete, is particularly selective about the chemical composition of the aggregate: limestone (about the $65 \%$ b.w.), silica (about the $25 \%$ b.w.), alumina (about the $4-$ $10 \%$ b.w.) and ferric oxide (about 1-3\% b.w.) are the main components, and magnesium, sodium, potassium oxides, sulphates, chlorides and phosphorous are undesiderable constituents [11, 12]. CR, FPM and MD1 samples underwent further chemical analyses, to evaluate their potential reuse in the concrete industry added to traditional raw materials (see Table 4): actually these wastes are characterized by a relevant fine fraction and they are rich of silica; on the other hand these residues have a very low content of noxious elements such as alkali, magnesium, sulphates, chlorides and phosphorous. Considering the chemical characterization results and concrete industry requirements, the authors evaluated possible mixtures made of traditional raw materials (limestone and clay) and the considered residues (see Table 5).

Table 5: Composition of two possible mixtures for the recycling of some Teksid foundry plant residues in Portland concrete production.

\begin{tabular}{|cccc|}
\hline residue & $\begin{array}{c}\% \\
\text { residue }\end{array}$ & $\begin{array}{c}\% \\
\text { clay }\end{array}$ & $\begin{array}{c}\% \\
\text { limestone }\end{array}$ \\
\hline $\begin{array}{c}\text { Mud from dust abatement on } \\
\text { moulding lines (FPM) }\end{array}$ & 18 & 7 & 75 \\
$\begin{array}{c}\text { Not inert fine particles from } \\
\text { moulding sand reclamation (NIF) }\end{array}$ & 8 & 14 & 78 \\
\hline
\end{tabular}

Because of their high silica fraction and low heavy metals content, the $\mathrm{CR}$ residue and the inert fine particles produced by the moulding sand reclamation plant may be recycled in white concrete production.

On the grounds of the results of the performed physical and chemical characterization and of the performed laboratory tests, the authors suggest to feed the already existing exhaust sand reclamation plant on the 


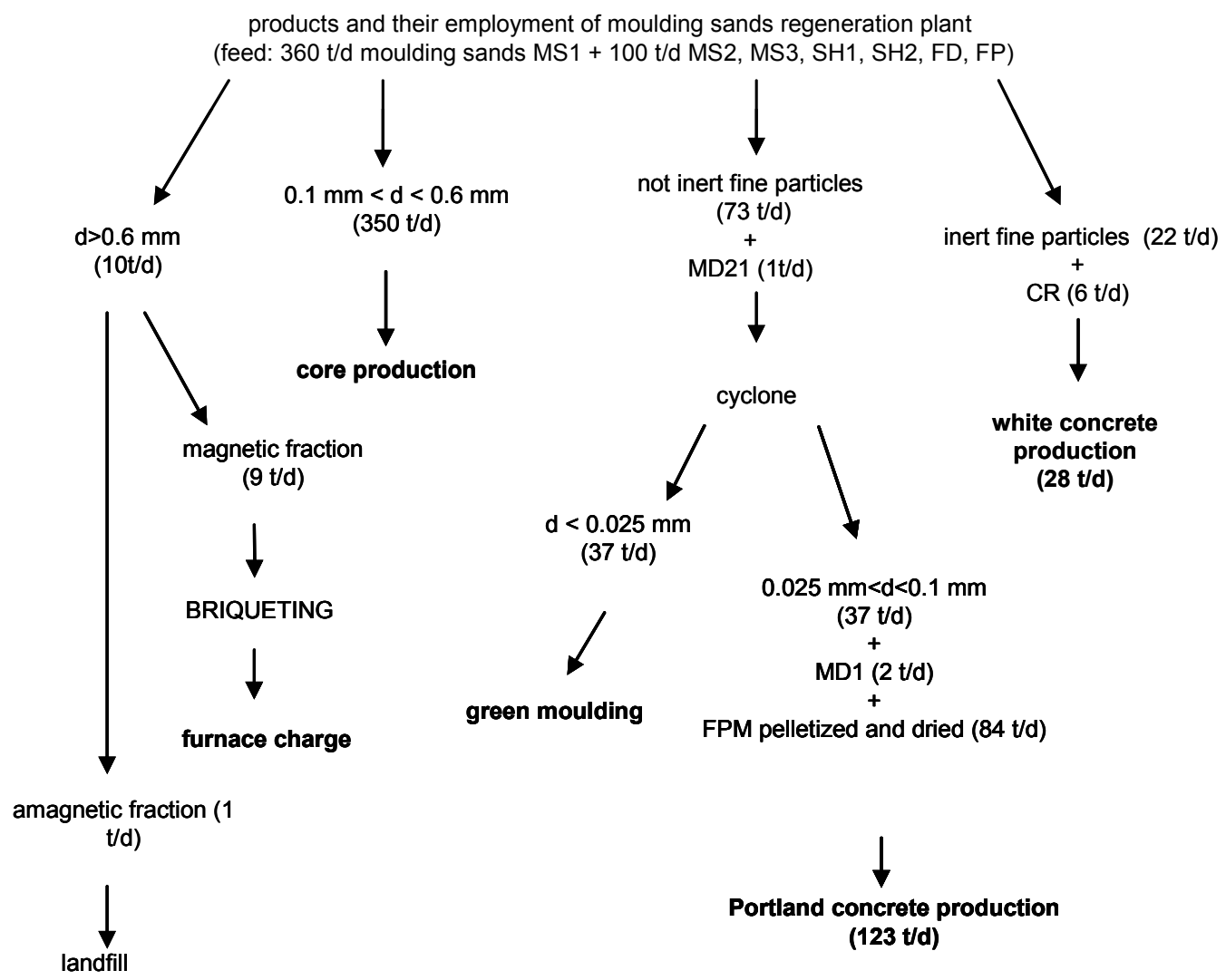

Fig. 3: Suggested solutions for Teksid foundry wastes recycling and/or reuse

moulding sands coming from shakeout $(360 \mathrm{t} / \mathrm{d})$, as planned, but also with shakeout under level sands, dusts from first shotting and moulding lines, furnaces, pavements and final shotting, adding about $100 \mathrm{t} / \mathrm{d}$ of residues and enhancing the economic convenience of the performances of a super sized plant. The authors tested on laboratory scale the mentioned reclamation process, including some additional treatments, and suggest the following reuse/recycling solutions for the products (see Figure 3):

- above $0.6 \mathrm{~mm}$ dimensions $(10 \mathrm{t} / \mathrm{d})$ : this fraction is essentially made of shotting steel globes and cast iron aggregates; a magnetic separation under a $500 \div 1000$ Gauss magnetic field revealed a $90 \%$ b.w. magnetic product, which may be briqueted and reused in the furnace charge;

- between $0.1 \mathrm{~mm}$ and $0.6 \mathrm{~mm}$ dimensions $(350 \mathrm{t} / \mathrm{d})$ : this fraction is mainly made of silica sand, that may be reused in cors production;

- not inert fine particles $(74 \mathrm{t} / \mathrm{d})$ : this material may undergo to a dry separation to be divided into two fractions on a $0.025 \mathrm{~mm}$ threshold; the authors calculated a cost of about $100,000 €$ for a proper cyclone. The below $0.025 \mathrm{~mm}$ fraction $(37 \mathrm{t} / \mathrm{d})$, made of mineral coal and bentonite, may be reused in moulding operations; the between 0.025 and 0.1 $\mathrm{mm}$ fraction $(37 \mathrm{t} / \mathrm{d})$, together with the pelletized and dried mud from dust abatement on moulding lines $(840 \mathrm{t} / \mathrm{d})$, may be recycled in Portland concrete production. Pelletization and drying costs were calculated into $7 € / \mathrm{t}$ of mud;

- inert fine particles $(22 \mathrm{t} / \mathrm{d})$ together with dust from core thermal regeneration plant $(6 \mathrm{t} / \mathrm{d})$ may be recycled in white concrete production.

At the moment of this research the foundry residues were mainly landfilled; the authors suggest some opportunities to significantly change this trend, reaching an amount of recovered wastes about equal to $589 \mathrm{t} / \mathrm{y}$ (see Table 6), that may be partially reused in the plant (about $65 \%$ b.w.) and partially recycled (about $33 \%$ b.w.) in concrete production. The hypothesized recycle and/or reuse operations require simple technical changes, with low investments costs (see Table 6), that are justified by the raw materials saving and the economic and environmental advantages due to landfill space saving.

An economic evaluation according to the Italian situation of the hypothesized technical solutions is reported in Table 6 . The economic analysis shows that the involved treatment costs are practically covered by the raw material economic saving with noticeable 
economic advantages in comparison with the actual situation (saving of $35,000 € / \mathrm{d}$ ).

Table 6. Economic evaluation of the hypothesized reuse/recycle solutions

\begin{tabular}{lc}
\hline disposal and treatment costs & \\
\hline magnetic separation and briqueting & $5 € / \mathrm{t}$ \\
drying and briqueting & $7 € / \mathrm{t}$ \\
moulding sand regeneration treatment & $35 € / \mathrm{t}$ \\
cyclone treatment & $2 € / \mathrm{t}$ \\
\hline hypothesized economic values (referred to Italy) & $40 € / \mathrm{t}$ \\
\hline new sand & $60 € / \mathrm{t}$ \\
new bentonite & $100 € / \mathrm{t}$ \\
materials for furnace charge & $0 € / \mathrm{t}$ \\
materials for concrete production & $35160 € / \mathrm{d}$ \\
\hline actual landfilling costs for wastes* with a potential & \\
market (589 t/d) & $17196 € / \mathrm{d}$ \\
foreseen treatment and landfilling costs according \\
to the hypothesized reuse/recycling alternatives \\
raw material saving & $17120 € / \mathrm{d}$ \\
\hline
\end{tabular}

* MS1, MS2, MS3, FPM, MD1, MD2, SH1, SH2, FD, FP, CR

\section{ACKNOWLEDGEMENT}

This research was performed under the financial support of Teksid Italia SpA.

\section{REFERENCES}

1. EPA United States Environmental Protection Agency 1981. Summary of factors affecting compliance by ferrous foundries, vol.1, pp. 34-49, EPA-340/1-80-020, Washington DC, US.

2. EPA United States Environmental Protection Agency 1997. Profile of the Metal Casting Industry, pp.15-22, 77-84, EPA/310/R-97/004, Washington DC, US.
3. Schleg, F. 2000: Guide to casting and moulding processes. Engineered Casting Solutions 2 (3), pp.18-27.

4. Luther, N.B. 1997: Metal casting and moulding processes. Casting Source Directory 7(1), 29-35

5. EPA United States Environmental Protection Agency 1992. Guides to Pollution Prevention, Metal Casting and Heat Treating Industry, pp.512, EPA/625/R-92/009, Washington DC, US.

6. M.C.Zanetti, S.Fiore 2003, Foundry processes: the recovery of green moulding sands for core operations, Resources, Conservation and Recycling, vol. 38, Issue 3, pp.243-254.

7. M.C.Zanetti, S.Fiore 2003, Foundry wastes recycling in moulding operations and in the ceramic industry, Waste Management \& Research, vol. 21, pp.235-242.

8. M.C.Zanetti, S.Fiore, C.Clerici 2004, Reuse of foundry sands for cores and glass production, Journal of Solid Waste Technology and Management, vol. 30, No.1, pp. 28-36.

9. UNI, Italian National Standards Body, Foundry sand. Sampling and test methods, UNI 4628:1976.

10. APHA, AWWA, WEF 1998. Standard methods for the examination of water and wastewater, $20^{\text {th }} \mathrm{Ed}$., Washington DC, US.

11. Labahn, O. 1983. Cement engineers' handbook, Wiesbaden, Bauverlag.

12. EPA, United States Environmental Protection Agency 1995. Profile of the Stone, Clay, Glass and Concrete industry, pp. 11-12, 21-23, EPA/310-R95-017, Washington DC, US. 